\title{
Sighting of critically endangered Red-headed vulture Sarcogyps calvus (Scopoli, 1786) in Palamau Tiger Reserve, Jharkhand, India
}

\author{
Amrendra K. Singh, S. K. Sajan*, Jenis R Patel, M. K. Bakshi \\ Wild India, Behind DAV public school, Gandhi Nagar, Kanke, Ranchi- 834008 \\ *Correspondence author: sksajan.sajan@gmail.com
}

http://dx.doi.org/10.4314/vulnew.v73i1.6

\section{Introduction}

Palamau Tiger Reserve $\left(23^{\circ} 25^{\prime}\right.$ to $23^{\circ} 55^{\prime} \mathrm{N}$ and $83^{\circ} 50^{\prime}$ to $84^{\circ} 36^{\prime} \mathrm{E}$ ), was notified in 1973 as one of India's first nine tiger reserves established under Project Tiger. It is located under the western part of the Chhotanagpur plateau and is part of the Central India landscape (Anon, 2013). The vegetation types are broadly categorised as dry moist forest, dry Sal forest, moist Sal forest, high level plateau Sal forest and moist forest (Champion and Seth 1968).

Vultures play an important role as natural scavengers in the ecosystem and help prevent hazardous infectious disease like anthrax and rabies (Ogada et al. 2012). However, the widespread use of non-steroidal anti-inflammatory drugs (NSAIDs), mainly diclofenac, caused serious declines of vultures across south Asia (Oaks et al. 2004). Globally, there are 16 species of Old World vulture and nine of these are found within the Indian subcontinental region (Ali \& Ripley 1987). Four species: White-rumped vulture Gyps bengalensis, Slenderbilled vulture Gyps tenuirostris, Long-billed Vulture Gyps indicus and Red-headed Vulture Sarcogyps calvus are listed as critically endangered and Egyptian Vulture Neophron percnopterus is listed as endangered under the International Union for Conservation of Nature (IUCN) Red List (Birdlife International 2013).

Historical records of Red-headed Vulture exist for Lohardagga in Jharkhand and Manbhum in West Bengal (Dutta et al. 2004), during 
the systematic ornithological survey was carried out by Zoological Survey of India (Fig. 1), but no recent records are reported for the area around Palamu Tiger Reserve.

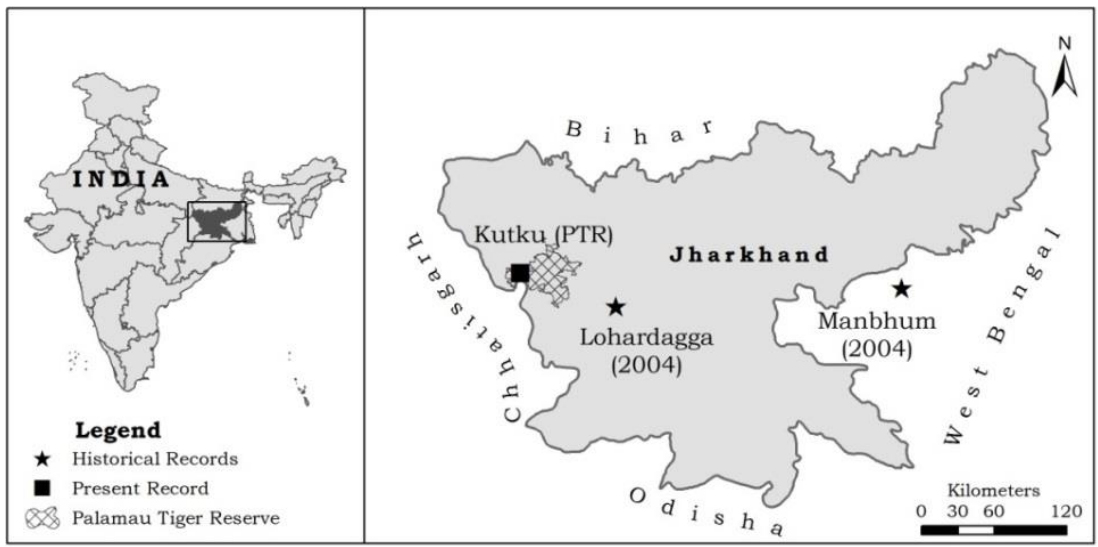

Figure 1: Map showing the historical and present record of Sarcogyps calvus in Jharkhand.

\section{Observation}

A Red-headed Vulture, also known as the Pondicherry Vulture, was sighted on $17^{\text {th }}$ April, 2014 at 10.30 am, soaring about 30 meters above the ground in clear skies near Kutku village $\left(23^{\circ} 40^{\prime} 47.37^{\prime \prime} \mathrm{N}\right.$ and $83^{\circ}$ $58^{\prime} 13.86^{\prime \prime} \mathrm{E}$ ), within the Daltonganj Core area of Project Tiger. In flight, diagnostic features include a white band on the underside of the wing, and white patches on the thigh and base of the neck are seen through binoculars (Baker 1928); we took photographs for further identification of the species (Fig. 2). The linear distance from historical records is about $77.7 \mathrm{~km}$ and $289 \mathrm{~km}$ away from Lohardagga and Manbhum respectively (Fig. 1). We discussed with local communities and forest staff about the presence of vulture species found in this region. They replied that after the 1999 cyclone they have never seen Red-headed Vulture in PTR. 


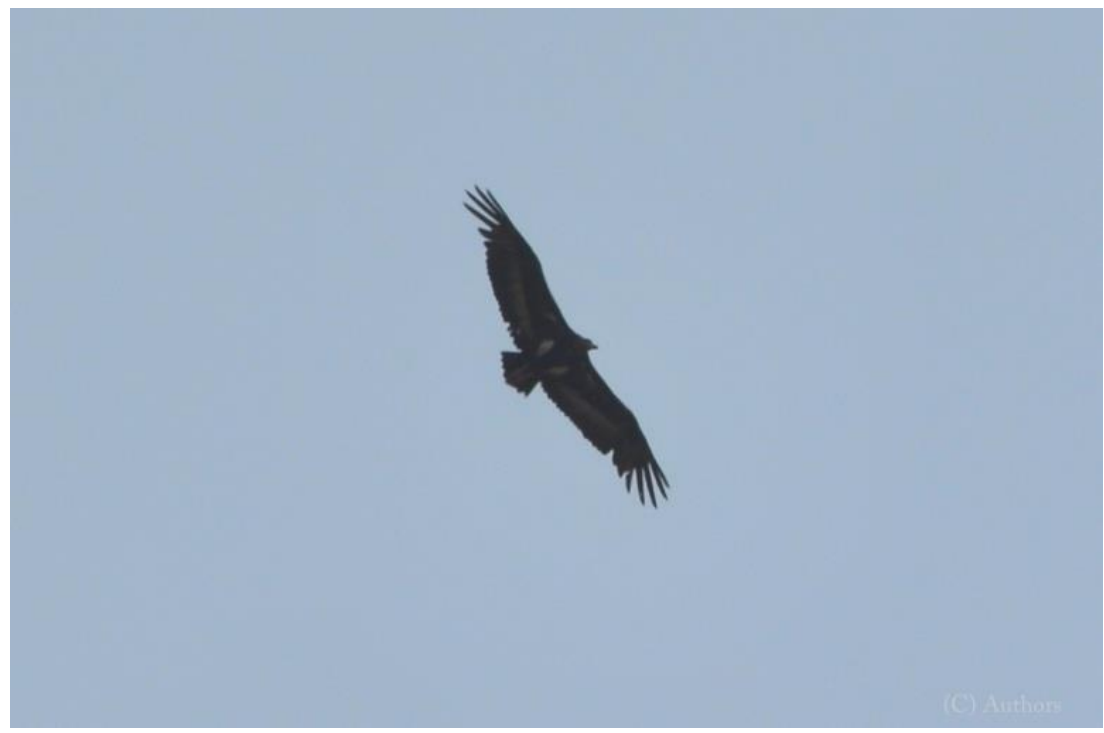

Figure 2: Sarcogyps calvus near Kutku village in Palamau Tiger Reserve.

\section{Conservation}

In Palamau Tiger Reserve, the shrinkage of breeding habitat, shortage of food, urbanisation, changes in agricultural patterns, livestock rearing and the use of chemical contaminated foods are serious causes of population decline. Ornithologists suggested that between 1999 and 2003 the population of Sarcogyps calvus decreased by $41-44 \%$ (Cuthbert et al. 2006). A systematic vulture census needs to be carried out to understand the actual population size and roosting places of Sarcogyps calvus for long term conservation of this critically endangered species in the Palamu Tiger Reserve before its extinction from world.

\section{Acknowledgements}

Thanks to S. R. Joy (librarian, Zoological Survey of India, Kolkata) for providing necessary references to enhance the manuscript. We place our sincere gratitude to Shri SHE Kazmi, field director and Shri A. K. Mishra, DFO for provide permission to carry out the survey in Palamau Tiger Reserve. 
We would like to thanks to all the forest staff for their fearless efforts on fieldwork.

\section{References}

Ali, S. \& Ripley, S. 1987. The Handbook of the Birds of India and Pakistan. 2nd Compact Edition. Oxford University Press, Delhi.

Anon. 2013. Tiger Conservation Plan, Palamau Tiger Reserve, Jharkhand, pp. $1-236$.

Baker, E. \& Stuart, C. 1928. Accipitres, Columbae, Pterocletes, Gallinae, Hemipodii, Second Edition, Fauna of British India including Ceylon and Burma 5: 9-10.

BirdLife International. 2013. Sarcogyps calvus. The IUCN Red List of Threatened Species. Version 2014.2. 〈www.iucnredlist.org>. Downloaded on 19 September 2014.

Champion, S.H. \& Seth, S.K. 1968. A revised forest types of India. Manager of Publications, Government of India, Delhi.

Cuthbert, R., Green, R.E., Ranade, S., Saravanan, S., Pain, D.J., Prakash, V \& Cunningham, A. A. 2006. Rapid population declines of Egyptian Vulture (Neophron percnopterus) and Red-headed Vulture (Sarcogyps calvus) in India. Animal Conservation 9: 349-354.

Dutta, B.B., Roy, S.B., Datta, B.K \& Dasgupta, J.M. 2004. State Fauna Series II: Fauna of Bihar (Including Jharkhand). Zoological Survey of India Part I: pp73-142.

Oaks, J.L., Gilbert, M., Virani, M.Z., Watson, R.T., Meteyer, C.U., Rideout, B.A., Shivaprasad, H.L., Ahmed, S., Chaudhry, M.J., Arshad, M., Mahmood, S., Ali, A. \& Khan, A.A. (2004). Diclofenac residues as the cause of vulture population decline in Pakistan. Nature 427: 630-633.

Ogada, D.L., Keesing, F. \& Virani, M.Z. (2012). Dropping dead: causes and consequences of vulture population declines worldwide. Annals of the New York Academy of Sciences 1249: 57-71. 